\title{
Primary neuroendocrine neoplasm of the esophagus - Report of 14 cases from a single institute and review of the literature
}

\author{
Francisco TUSTUMI ${ }^{1}$, Flavio Roberto TAKEDA ${ }^{2}$, Rodrigo Hideki UEMA ${ }^{3}$, \\ Guilherme Luiz Stelko PEREIRA ${ }^{2}$, Rubens Antonio Aissar SALLUM ${ }^{1}$ and Ivan CECCONELLO ${ }^{1}$
}

Received 9/7/2016 Accepted 22/8/2016

\begin{abstract}
Background - Most prevalent esophageal neoplasm is squamous cell carcinoma and adenocarcinoma. Other tumors are uncommon and poorly studied. Primary neuroendocrine esophageal neoplasm is a rare carcinoma and most of its therapy management is based on lung neuroendocrine studies. Neuroendocrine tumors can be clustered in the following subtypes: high grade (small cell carcinoma or large cell carcinoma) and low grade (carcinoids). Objective - The present study aims to assess clinical and pathological neuroendocrine esophageal tumors in a single oncologic center. Methods - A retrospective analysis of patients and review of the literatures was performed. Results - Fourteen patients were identified as neuroendocrine tumors, 11 male and 3 female patients. Mean age was 67.3 years old. Ten patients were classified as small cell, 3 as large cell and 1 as carcinoid. Four patients presented squamous cell carcinoma simultaneously and 1 also presented adenocarcinoma. Main sites of metastasis were liver, peritoneum, lung and bones. Most patients died before 2 years of follow-up. Patient with longer survival died at 35 months after diagnosis. Conclusion - Neuroendocrine esophageal tumors are rare; affect mainly men in their sixties or seventies. High grade tumors can be mixed to other subtypes neoplasms, such as adenocarcinoma and squamous cell carcinoma. Most of these patients have poor overall survival rates.
\end{abstract}

HEADINGS - Esophageal neoplasms. Carcinoid tumor. Neuroendocrine carcinoma.

\section{INTRODUCTION}

Esophageal cancer is a rapidly progressive disease with poor survival rates. Most of these tumors are either adenocarcinoma or squamous cell carcinoma histologic types. Less frequent cancer subtypes, such as melanoma, lymphomas or neuroendocrine tumors are uncommon and poorly explored ${ }^{(34)}$.

Neuroendocrine esophageal neoplasms are rare and most of studies are case reports. The classification and nomenclature are not well established and knowledge acquired in neuroendocrine neoplasms of lungs and certain gastrointestinal sites, such as pancreas, usually guide esophageal neuroendocrine management.

Neuroendocrine neoplasm subtypes are grouped based upon shared neuroendocrine features. The subtypes comprise small cell carcinoma, large cell neuroendocrine carcinoma, typical carcinoid, and atypical carcinoid ${ }^{(140)}$.

This article is a descriptive report of clinical and pathological features of cases of neuroendocrine esophageal tumors in our institute, along 8 years of experience, and a review of the literature.

\section{METHODS}

All esophageal cancer patients' charts of our institution were reviewed, between 2008 and 2016. Cases of neuroendocrine neo- plasm were identified and clinical and pathological features of these patients were assessed.

For review of the literature, database search was performed in MEDLINE, with search algorithm: ("neuroendocrine" [All Fields] OR "carcinoid tumor" [MeSH Terms] OR "carcinoid" [All Fields] OR "small cell carcinoma" [MeSH Terms] OR "large cell carcinoma") AND ("oesophagus" [All Fields] OR "esophagus" [All Fields] OR esophageal [All Fields]). Period searched up to 2016, with no idiom restriction. Review studies and no full-text studies were excluded. When more than one publication of a single trial existed, only the publication with the most complete data was included.

\section{RESULTS}

A total of 1,574 of esophageal cancers were reviewed. Fourteen $(0.89 \%)$ cases of neuroendocrine neoplasm were selected, 3 female and 11 male patients (Table 1). Mean age was 67.3 (range 47 to 80 ) years old. Table 2 shows immunohistochemical panel of neuroendocrine neoplasm.

Three were classified as large cell esophageal carcinoma (LCEC), 10 as small cell carcinoma (SCEC), and 1 as carcinoid. Distal and middle esophagus were more often affected.

Endoscopic appearance was usually a vegetating and infiltrative tumor, except carcinoid subtype. (Figure 1).

Declared conflict of interest of all authors: none

Disclosure of funding: no funding received

${ }^{1}$ Cirurgia do Aparelho Digestivo, Faculdade de Medicina, Hospital das Clínicas, USP, SP, Brasil; ${ }^{2}$ Instituto do Câncer, Faculdade de Medicina, Hospital das Clínicas, USP, SP, Brasil; ${ }^{3}$ Faculdade de Medicina, Hospital das Clínicas, Universidade de São Paulo, SP, Brasil.

Correspondence: Francisco Tustumi. Faculdade de Medicina, do Hospital das Clínicas, da Universidade de São Paulo. Rua Teodoro Sampaio, 632, ap. 71 - CEP: 05406-000 - São Paulo, SP, Brasil. E-mail: franciscotustumi@gmail.com 
TABLE 1. Main characteristics of the 14 patients diagnosed with neuroendocrine tumor

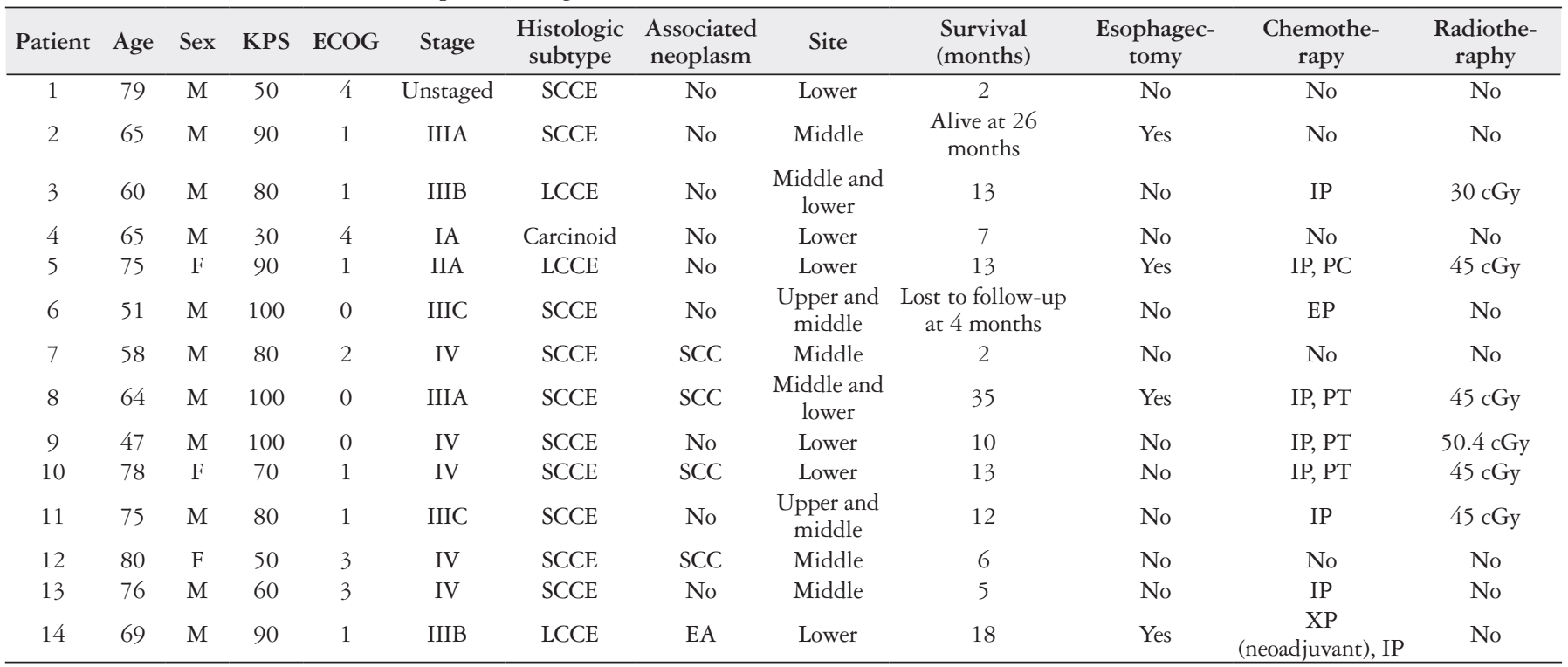

SCEC: small cell esophageal cancer; LCEC: large cell esophageal cancer; KPS: Karnofsky Performance Status; ECOG: Eastern Coorporative Oncology Group; SCC: squamous cell carcinoma; EA: esophageal adenocarcinoma; PC: Paclitaxel and Carboplatin; PT: Cisplatin and Paclitaxel; IP: Irinotecan and Cisplatin; EP: Etoposide and Cisplatin; XP: Capecitabine and Cisplatin.

TABLE 2. Immunohistochemical panel of patients with esophageal neuroendocrine neoplasm

\begin{tabular}{|c|c|c|c|c|c|c|c|c|c|c|c|c|}
\hline Patient & $\begin{array}{l}\text { Grade of cellular } \\
\text { differentiation }\end{array}$ & Syp & $\operatorname{CgA}$ & $\mathrm{Ki}-67(\%)$ & Ber-EP4 & Ck7 & AE-1/AE-3 & 35BH11 & P63 & $\mathrm{CD} 56$ & TTF-1 & Vimentin \\
\hline 2 & Poorly & NP & - & $80-90$ & NP & NP & NP & + & - & + & + & NP \\
\hline 3 & Poorly & NP & + & 90 & + & NP & - & NP & - & NP & NP & NP \\
\hline 5 & Poorly & + & + & $>90$ & NP & + & NP & NP & - & NP & NP & NP \\
\hline 6 & Poorly & + & + & 90 & $\mathrm{NP}$ & NP & NP & NP & $\mathrm{NP}$ & NP & + & NP \\
\hline 7 & Poorly & + & + & $\mathrm{NP}$ & + & NP & NP & NP & + & NP & NP & NP \\
\hline 10 & Poorly & + & + & NP & NP & - & + & + & - & + & + & NP \\
\hline 11 & Poorly & NP & - & NP & - & $\mathrm{NP}$ & + & + & - & + & NP & NP \\
\hline 12 & Poorly & + & + & 90 & NP & NP & + & NP & + & + & NP & NP \\
\hline 13 & Poorly & NP & NP & NP & NP & NP & + & + & + & + & + & + \\
\hline 14 & Poorly & + & + & 70 & - & + & NP & NP & - & NP & NP & NP \\
\hline
\end{tabular}

(+): positive; (-): negative; Syp: Synaptophysin; CgA: Chromogranine A; Ck: Cytokeratin; NP: not performed.

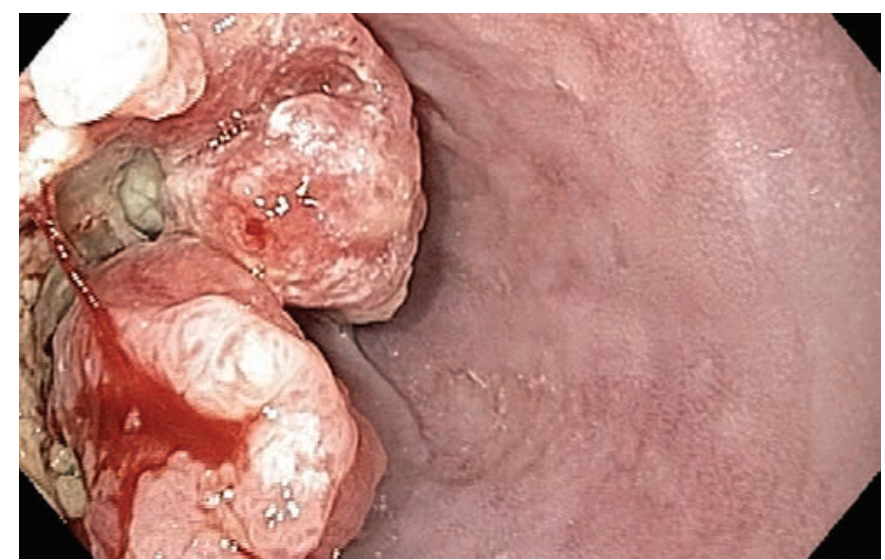

FIGURE 1. Endoscopic view of a high grade neuroendocrine neoplasm. It shows a circumferential infiltrative and ulcerating tumor.
Main symptoms were dysphagia (14/14) and weight loss (mean $11.7 \pm$ Std Dev $6.3 \mathrm{~kg}$ ). Duration of symptoms prior to diagnosis was $6.2 \pm$ Std Dev 3.3 months.

Associated squamous cell carcinoma could be seen in $4 / 14$ cases and associated adenocarcinoma (adenoneuroendocrine) in 1/14. Immunohistochemical panel can be seen in Table 2 .

Of these patients, $10 / 14$ had previous history of high amount of alcohol intake and 12/14 were tobacco smokers.

Most cases were diagnosed at late stages (III and IV), accordingly AJCC 7th Edition ${ }^{(122)}$. Metastasis sites were lungs, liver, adrenal, peritoneal and bones.

Cause of death was pneumonia in five cases, urinary tract infection in one case, and sepsis of unknown origin in one case. The five remaining patients, cause of death was not clearly established.

Curative intent surgery was performed in $4 / 14$ patients, of which one is still alive at 26 months of follow-up. 
Most cases had low survival rates (see Figure 2). Patient who lived longer died at 35 months of pneumonia. Patient "2" is still alive without disease up to this paper publication. Patients "6" lost to follow-up, with disease. The remaining patients died with disease.

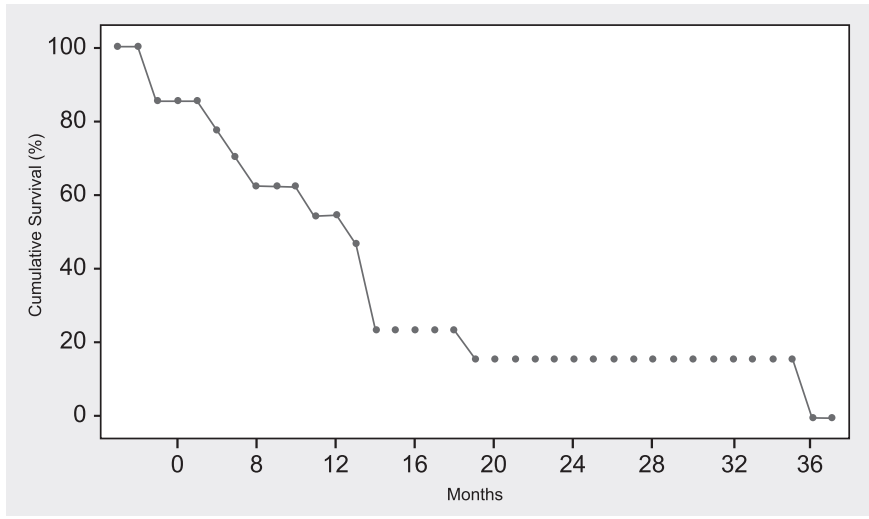

FIGURE 2. Kaplan-Meir curve for survival of patients with esophageal neuroendocrine neoplasm

Patient diagnosed with carcinoid tumor presented myelofibrosis during follow-up, leading to pancytopenia and early death.

\section{Review of the literature}

For review of the literature, a total number of articles by database search were 1007. After excluding duplicates and screening by title and abstract, 154 articles remained ${ }^{(1-33,35-79,81-115,117-119, ~ 121, ~ 123-139, ~ 141-162) . ~}$

A cumulative sample size of 2,957 patients was evaluated, in 20 different countries. Of this patients, 2,899 were SCEC (77\% in East countries; $23 \%$ in West countries); 35 were LCEC ( $6 \%$ in East countries; $94 \%$ in West countries); and 23 were carcinoid (54\% in East countries; $43 \%$ in West countries).

Among all esophageal malignances, prevalence of SCEC was $1.05 \%$ in East countries and $0.72 \%$ in West countries. There are few studies data concerning carcinoid tumors and LCEC prevalence. Most of the studies approaching LCEC were performed in West countries.

Neoplasms were staged as limited disease (LD) or extend disease (ED). LD is defined as disease confined to the esophagus and adjacent organs with or without regional lymph node involvement while ED is defined for neoplasm with distant spread ${ }^{(59)}$. Main features and differences concerning neuroendocrine subtypes are presented in Table 3.

\section{DISCUSSION}

Neuroendocrine esophageal neoplasms are exceedingly rare, and hence there are few large sample clinical studies approaching this issue. Consequently, most of the knowledge is based on neuroendocrine lung neoplasms.

Neuroendocrine lung tumors are classified as low grade (carcinoids) or as high grade (SCEC and LCEC) ${ }^{(120)}$.

SCEC have nuclear appearance, with finely granular chromatin; lack of predominant nucleoli; nuclear fragility; fusiform cells; scant cytoplasm and indistinct cells borders; high mitotic rate; and large area of necrosis ${ }^{(120)}$. (Figure 3).

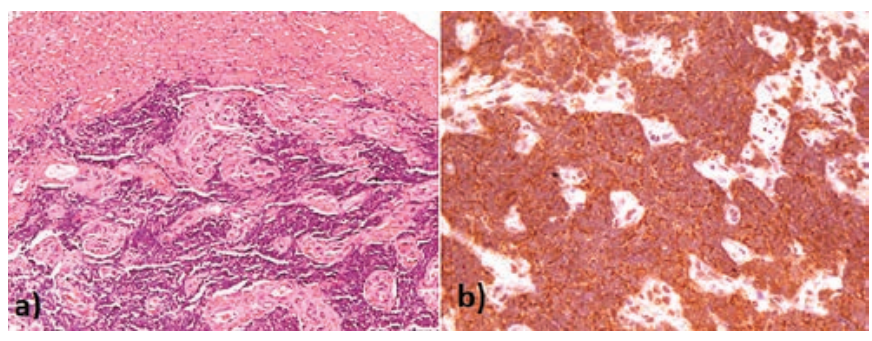

FIGURE 3. Small cell esophageal carcinoma (SCEC). High power view of infiltrative proliferation of round small cells with scanty cytoplasm and dark nuclei with intense crush artifacts lined by ulcerative epithelium (a) (HE, 200x). CD56 positive (b) (400x).

TABLE 3. Main features and differences concerning neuroendocrine subtypes

\begin{tabular}{|c|c|c|c|c|c|c|c|}
\hline & & SCEC & $\%$ & LCEC & $\%$ & Carcinoid & $\%$ \\
\hline \multirow[t]{2}{*}{ Prevalence } & East countries & $1,527(145,717)$ & 1.048 & Unknown & - & Unknown & - \\
\hline & West countries & $533(73,290)$ & 0.727 & $5(1,105)$ & 0.452 & Unknown & - \\
\hline \multirow[t]{2}{*}{ Age } & Mean & 63.8 & - & 62.1 & - & 58.3 & - \\
\hline & $\geq 60 \mathrm{yr}$ & 581 & 51.74 & 4 & 100 & 9 & 42.9 \\
\hline \multirow[t]{2}{*}{ Sex } & $\mathrm{M}$ & 1,517 & 69.5 & 32 & 88.9 & 14 & 70 \\
\hline & $\mathrm{F}$ & 666 & 30.5 & 4 & 11.1 & 6 & 30 \\
\hline \multirow[t]{3}{*}{ Tumor site } & Upper & 202 & 12.4 & 1 & 10 & 1 & 7.7 \\
\hline & Middle & 904 & 55.5 & 5 & 50 & 2 & 15,4 \\
\hline & Lower/GEJ & 523 & 32.1 & 4 & 40 & 10 & 76.9 \\
\hline \multirow[t]{2}{*}{ Stage } & LD & 1,519 & 70.2 & 16 & 55.2 & 13 & 100 \\
\hline & ED & 645 & 29.8 & 13 & 44.8 & 0 & 0 \\
\hline Tumor size & $<5 \mathrm{~cm}$ & 423 & 42.2 & 2 & 66 & 9 & 64.3 \\
\hline OS & $5 \mathrm{yr}$ & $144(1,853)$ & 7.7 & $0(1)$ & 0 & $6(7)$ & 86 \\
\hline
\end{tabular}

OS: overall survival; GEJ: gastroesophageal junction; SCEC: small cell esophageal cancer; LCEC: large cell esophageal cancer. 
LCEC presents non-small cell nuclear features (vesicular clumpy chromatin, predominant nucleoli), abundant cytoplasm, and large cell size ${ }^{(120)}$. (Figure 4).

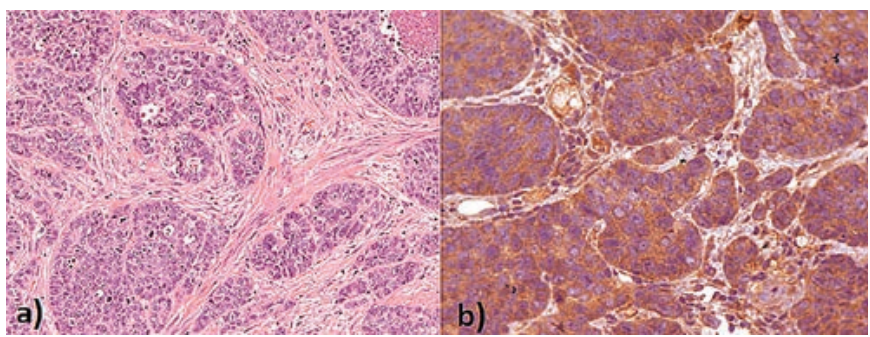

FIGURE 4. Large cell esophageal carcinoma (LCEC). Solid nests of large and intermediate cells, with eosinophilic cytoplasm, vesicular nuclei and prominent nucleoli, focal necrosis and high mitotic rate (a) (HE, 200x). Chromogranin positive (400x) (b).

Carcinoids typical morphology includes coarsely granular "salt and pepper" chromatin, overall uniformity, prominent vascularity, lack of prominent nucleoli, low mitosis rate. Usually no necrosis is seen ${ }^{(120)}$.

Esophageal high grade tumors tend to be aggressive. Usually, patients are diagnosed lately, with widespread disease, and with poor prognosis. Currently, clinical treatment strategies of high grade cancers neuroendocrine neoplasms are very limited and full of contradiction. High grade neoplasms are often regarded as a systemic disease and, just like in lung cancer, chemotherapy is the mainstay of therapy ${ }^{(17)}$. Additional therapy (surgery or radiotherapy) should be considered, but randomized controlled trials still unavailable ${ }^{(80,116)}$.

Our data suggests a much good prognosis for low grade neuroendocrine tumors, with high overall survival rate. For limited disease (LD) carcinoid, surgical intervention is the treatment of choice $^{(18)}$

Although low incidence of esophageal neuroendocrine tumors, our results give a better picture of the behavior of this rare condition. The present study shows this disease affects mainly men in sixties or seventies. Middle and lower esophageal thirds are most frequently affected. Nevertheless, future multicenter efforts are needed for randomized clinical trials evaluating therapeutic guidelines.

\section{ACKNOWLEDGMENT}

We would like to state our acknowledgment for Rafaela Brito Bezerra Pinheiro efforts on pathology analysis and microscopy pictures.

\section{Authors' contributions}

Tustumi F: study elaboration and data collect. Takeda FR: study elaboration. Uema RH: data collect. Pereira GLS: oncologic review. Sallum RAA: orientation of the study. Cecconello I: orientation of the study.

Tustumi F, Takeda FR, Uema RH, Pereira GLS, Sallum RAA, Cecconello I. Neoplasia neuroendócrina primária de esôfago - Relato de 14 casos e revisão de literatura. Arq Gastroenterol. 2017,54(1):4-10.

RESUMO - Contexto - As neoplasias esofágicas mais prevalentes são o adenocarcinoma e o carcinoma espinocelular. Outros subtipos histológicos são incomuns e pouco estudados. Neoplasia neuroendócrina esofágica é uma patologia rara e seu manejo atualmente se baseia nos conhecimentos prévios de tumores neuroendócrinos de pulmão. Tumores neuroendócrinos podem ser divididos nas seguintes formas: alto grau (pequenas células ou grandes célula) e baixo grau (carcinoides). Objetivo - Avaliar clínica e patologicamente os tumores de esôfago em um centro oncológico referenciado. Métodos - Foi realizada análise retrospectiva e revisão da literatura de neoplasias neuroendócrinas de esôfago. Resultados - Foram identificados 14 pacientes com tumores neuroendócrino, sendo 11 homens, 3 mulheres. Idade média foi de 67,3 anos de idade. Desses pacientes, 10 foram classificados como pequenas células, 3 como grandes células e 1 como carcinoide. Foram encontrados quatro casos de tumor misto neuroendócrino e carcinoma espinocelular, e um caso de tumor misto adenoneuroendócrino. Principal sítio de metástases foi fígado, peritônio, pulmão e ossos. A maioria dos pacientes foi a óbito em até 2 anos de seguimento. Paciente com sobrevida mais longa foi a óbito após 35 meses do diagnóstico. Conclusão - Neoplasias neuroendócrinas de esôfago são raras, afetam principalmente o sexo masculino na $7^{\mathrm{a}}$ ou $8^{\mathrm{a}}$ década de vida. A maioria dos pacientes com tumores de alto grau tem sobrevida curta.

DESCRITORES - Neoplasias esofágicas. Tumor carcinoide. Carcinoma neuroendócrino.

\section{REFERENCES}

1. Adachi K, Tateno Y, Okada H. An esophageal collision tumor. Clin Gastroenterol Hepatol. 2014;12:17-8.

2. Akagi I, Miyashita M, Makino H, Nomura T, Shimanuki K, Satake S, Hagiwara N, Uchida E. Small cell carcinoma of the esophagus: a case report. J Nippon Med Sch. 2014;81:97-100.

3. Ando T, Hosokawa A, Yamawaki H, Hasumoto Y, Kajiura S, Itaya Y, et al. Esophageal small-cell carcinoma with syndrome of inappropriate secretion of antidiuretic hormone. Intern Med. 2011;50:1099-103.

4. Atsumi K, Shioyama Y, Nomoto S, Ohga S, Toba T, Sasaki T, et al. Chemoradiation for small cell esophageal carcinoma: report of 11 cases from multi-institution experience. J Radiat Res. 2010;51:15-20.

5. Asayama M, Fuse N, Yoshino T, Yano T, Tahara M, Doi T, et al. Amrubicin for the treatment of neuroendocrine carcinoma of the gastrointestinal tract: a retrospective analysis of five cases. Cancer Chemother Pharmacol. 2011;68:1325-30.

6. Atsumi K, Shioyama Y, Nomoto S, Ohga S, Toba T, Sasaki T, et al. Chemoradiation for small cell esophageal carcinoma: report of 11 cases from multi-institution experience. J Radiat Res. 2010;51:15-20.
7. Babich JP, Klein J, Khullar P, Friedel DM. Endoscopic mucosal resection of a mid-esophageal carcinoid with EUS guidance. Endoscopy. 2010;42(Suppl 2):E302-3.

8. Basu S, Nair N. (18)FDG PET in primary oat cell carcinoma of the esophagus. Indian J Cancer. 2005;42:60-2.

9. Bennouna J, Bardet E, Deguiral P, Douillard JY. Small cell carcinoma of the esophagus: analysis of 10 cases and review of the published data. Am J Clin Oncol. 2000;23:455-9.

10. Bibeau F, Chateau MC, Guiu M, Assenat E, Azria D, Lavaill R, et al. Small cell carcinoma with concomitant adenocarcinoma arising in a Barrett's oesophagus: report of a case with a favourable behaviour. Virchows Arch. 2008;452:103-7.

11. Briggs JC, Ibrahim NB. Oat cell carcinomas of the oesophagus: a clinico-pathological study of 23 cases. Histopathology. 1983;7:261-77.

12. Brown RS Jr, Peppercorn MA, Farraye FA, Glotzer DJ, Antonioli DA, Taylor G. Carcinoid tumor of the esophagus. J Clin Gastroenterol. 1994;19:338-9.

13. Caldwell CB, Bains MS, Burt M. Unusual malignant neoplasms of the esophagus. Oat cell carcinoma, melanoma, and sarcoma. J Thorac Cardiovasc Surg. $1991 ; 101: 100-7$ 
14. Cary NR, Barron DJ, McGoldrick JP, Wells FC. Combined oesophageal adenocarcinoma and carcinoid in Barrett's oesophagitis: potential role of enterochromaffin-like cells in oesophageal malignancy. Thorax. 1993;48:404-5.

15. Casas F, Ferrer F, Farrús B, Casals J, Biete A. Primary small cell carcinoma of the esophagus: a review of the literature with emphasis on therapy and prognosis. Cancer. 1997;80:1366-72.

16. Chatni SS, Ravindran HK, Narayanan A, Balakrishnan V. Small cell carcinoma of the esophagus. Saudi J Gastroenterol. 2008;14:149-50.

17. Chen SB, Yang JS, Yang WP, Weng HR, Li H, Liu DT, Chen YP. Treatment and prognosis of limited disease primary small cell carcinoma of esophagus. Dis Esophagus. 2011;24:114-9.

18. Chen KC, Chang YL, Pan CT, Lee YC. Esophageal atypical carcinoid tumor with tracheal invasion. J Thorac Cardiovasc Surg. 2007:134:524-5.

19. Chen WW, Wang F, Chen S, Wang L, Ren C, Luo HY, et al. Detailed analysis of prognostic factors in primary esophageal small cell carcinoma. Ann Thorac Surg. 2014;97:1975-81.

20. Chin K, Baba S, Hosaka H, Ishiyama A, Mizunuma N, Shinozaki E, et al. Irinotecan plus cisplatin for therapy of small-cell carcinoma of the esophagus: report of 12 cases from single institution experience. Jpn J Clin Oncol. 2008;38:426-31.

21. Chino O, Makuuchi H, Ozawa S, Shimada H, Nishi T, Kise Y, et al. Small Cell Type of Esophageal Neuroendocrine Carcinoma Resembling a Submucosal Tumor. Tokai J Exp Clin Med. 2015;40:36-9.

22. Chong FK, Graham JH, Madoff IM. Mucin-producing carcinoid ("composite tumor") of upper third of esophagus: a variant of carcinoid tumor. Cancer. 1979;44:1853-9.

23. Chow V, Law S, Lam KY, Luk JM, Wong J. Telomerase activity in small cell esophageal carcinoma. Dis Esophagus. 2001;14:139-42.

24. Chuah SK, Hu TH, Kuo CM, Chiu KW, Kuo CH, Wu KL, et al. Upper gastrointestinal carcinoid tumors incidentally found by endoscopic examinations. World J Gastroenterol. 2005;11:7028-32.

25. Clark T, Lee MJ, Munk PL. Primary small-cell carcinoma of the oesophagus with spontaneous oesophageal perforation following chemotherapy. Australas Radiol. 1996;40:250-3.

26. Cook MG, Eusebi V, Betts CM. Oat-cell carcinoma of the oesophagus: a recently recognized entity. J Clin Pathol. 1976;29:1068-73.

27. Cox PM, Vazir MH, Petty RK, Law S, Dhillon AP. Cerebellar cortical degeneration in association with small-cell carcinoma of the oesophagus. Neuropathol Appl Neurobiol. 1989;15:175-83.

28. Craig SR, Carey FA, Walker WS, Cameron EW. Primary small-cell cancer of the esophagus. J Thorac Cardiovasc Surg. 1995;109:284-8.

29. Deepak P, Devi R, Pillai H. Esophageal small cell carcinoma with synchronous renal cell carcinoma: a case report with review of the literature. Case Rep Gastroenterol. 2011;5:196-200.

30. del Valle Ruiz SR, Torres Bermúdez JR, Montoya Tabares MJ, Merino Montes J, Sánchez de la Villa G. [Extrapulmonary small cell carcinoma located in the oesophagus. Cir Esp. 2010;88:47-8

31. Doherty MA, McIntyre M, Arnott SJ. Oat cell carcinoma of esophagus: a report of six British patients with a review of the literature. Int J Radiat Oncol Biol Phys. 1984;10:147-52.

32. Eccles DM, Allan SG, Sang CT, Cornbleet MA. Small cell carcinoma of the oesophagus: report of three cases and review of published cases. Thorax. 1989;44:749-50

33. Einspanier GR, Caleel RT, Milford AF 3rd. Carcinoid tumors of the esophagus: report of a case. J Am Osteopath Assoc. 1987;87:500-3.

34. Enzinger PC, Mayer. R. Esophageal Cancer. N Engl J Med. 2003;349:2241-52.

35. Feng JF, Huang Y, Zhao Q, Chen QX. Clinical significance of preoperative neutrophil lymphocyte ratio versus platelet lymphocyte ratio in patients with small cell carcinoma of the esophagus. Scientific World Journal. 2013:504365.

36. Feng W, Harada H, Zhang P, Mitsuya K, Zheng X, Yasui H, et al. Metastatic brain tumors from small-cell esophageal cancer: clinical characteristics and outcome. J Cancer Res Ther. 2014;10:256-8.

37. Fenlon HM, O'Keane C, Carney DN, Breatnach E. Imaging of small cell carcinoma of the oesophagus. Clin Radiol. 1995;50:634-8.

38. Fukuchi M, Sakurai S, Tsukagoshi R, Naitoh H, Kuwano H. A case of large cell neuroendocrine carcinoma of the esophagogastric junction. Esophagus. 2015;12:295-9.

39. Funakoshi S, Hashiguchi A, Teramoto K, Miyata N, Kurita S, Adachi M, et al. Second-line chemotherapy for refractory small cell neuroendocrine carcinoma of the esophagus that relapsed after complete remission with irinotecan plus cisplatin therapy: Case report and review of the literature. Oncol Lett. 2013;5:117-22.

40. Gao R, Zhang Y, Wen XP, Fu J, Zhang GJ. Chemotherapy with cisplatin or carboplatin in combination with etoposide for small-cell esophageal cancer: a systemic analysis of case series. Dis Esophagus. 2014;27:764-9.
41. Gollard R, Ellis C, VanderHarten C. Small cell/neuroendocrine tumors of the esophagus: presentation of two cases and review of the literature. Tumori. 2010;96:780-3

42. González LM, Sanz-Esponera J, Saez C, Alvarez T, Sierra E, Sanz-Ortega J. Case report: esophageal collision tumor (oat cell carcinoma and adenocarcinoma) in Barrett's esophagus: immunohistochemical, electron microscopy and LOH analysis. Histol Histopathol. 2003;18:1-5.

43. Goscinski MA, Xu R, Zhou F, Wang J, Yang H, Huang R, et al. Nuclear, cytoplasmic, and stromal expression of ZEB1 in squamous and small cell carcinoma of the esophagus. APMIS. 2015;123:1040-7.

44. Goto T, Watabe H, Kawakami T, Watanabe M, Nakano K, Takai A, et al. [A case of small cell carcinoma of the esophagus with remarkable response to chemotherapy with CPT-11 and CDDP]. Nihon Shokakibyo Gakkai Zasshi. 2007;104:1204-11.

45. Gumprich T, Johnen G, Hummel T, Jaworska M, Schmitz I, Müller KM. [A rare case of a neuroendocrine carcinoma of the esophagus. Intermediate between a wel-differentiated neuroendocrine carcinoma and a low-differentiated neuroendocrine carcinoma]. Pathologe. 2004;25:229-34.

46. Gupta NM, Goenka MK, Atri A, Vaiphei K. Carcinoid tumour of the oesophagus: a rare oesophageal cancer. Eur J Surg. 1996;162:841-4.

47. Heyes FL, Ayres J, Matthews HR. Oat cell carcinoma of esophagus. Int J Radiat Oncol Biol Phys. 1985;11:1573.

48. Hoang MP, Hobbs CM, Sobin LH, Albores-Saavedra J. Carcinoid tumor of the esophagus: a clinicopathologic study of four cases. Am J Surg Pathol. 2002;26:517-22

49. Horai T, Kobayshi A, Tateishi R, Wada A, Taniguchi H, Taniguchi K, et al. A cytologic study on small cell carcinoma of the esophagus. Cancer. 1978;41:1890-6.

50. Hosseini S, Salek R, Nasrolahi H, Mohammadianpanah M, Judi M. Small Cell Carcinoma of the Esophagus: Clinicopathological Features and Outcome of 22 Cases.Iran Red Crescent Med J. 2015; 17:e20353.

51. Hou X, Wei JC, Wu JX, Wang X, Fu JH, Lin P, Yang HX. Multidisciplinary modalities achieve encouraging long-term survival in resectable limited-disease esophageal small cell carcinoma. PLoS One. 2013;8:e69259.

52. Hsu PK, Li AF, Hsu WH. Simultaneous thoracotomy and laparotomy for small cell carcinoma of oesophagogastric junction. ANZ J Surg. 2008;78:723-4.

53. Huang Q, Wu H, Nie L, Shi J, Lebenthal A, Chen J, et al. Primary highgrade neuroendocrine carcinoma of the esophagus: a clinicopathologic and immunohistochemical study of 42 resection cases. Am J Surg Pathol. 2013;37: 467-83.

54. Huang YL, Chou SH, Chai CY, Hsu JS. Small cell neuroendocrine carcinoma of the esophagus. Kaohsiung J Med Sci. 2015;31:108-9.

55. Hudson E, Powell J, Mukherjee S, Crosby TD, Brewster AE, Maughan TS, et al. Small cell oesophageal carcinoma: an institutional experience and review of the literature. Br J Cancer. 2007;96:708-11.

56. Huncharek M, Muscat J. Small cell carcinoma of the esophagus. The Massachusetts General Hospital experience, 1978 to 1993. Chest. 1995;107:179-81.

57. Imai T, Sannohe Y, Okano H. Oat cell carcinoma (apudoma) of the esophagus: a case report. Cancer. 1978;41:358-64.

58. Isoyama Y, Shioyama Y, Nomoto S, Ohga S, Nonoshita T, Onishi K, et al. Carboplatin and etoposide combined with radiotherapy for limited-stage small-cell esophageal carcinoma: three cases and review of the literature. Jpn J Radiol. 2010;28:181-7.

59. Lv J, Linag J, Wang J, Wang L, He J, Xiao Z, Yin W. Primary Small Cell Carcinoma of the Esophagus. J Thorac Oncol. 2008;3:1460-5.

60. Johnson FE, Clawson MC, Bashiti HM, Silverberg AB, Broun GO Jr. Small cell undifferentiated carcinoma of the esophagus. Case report with hormonal studies. Cancer. 1984;53:1746-51.

61. Kadhim MM, Jespersen ML, Pilegaard HK, Nordsmark M, Villadsen GE. Mixed Adenoneuroendocrine Carcinoma Is a Rare but Important Tumour Found in the Oesophagus. Case Rep Gastrointest Med. 2016;2016:9542687.

62. Kanamoto A, Nakanishi Y, Ochiai A, Shimoda T, Yamaguchi H, Tachimori $\mathrm{Y}$, et al. A case of small polypoid esophageal carcinoma with multidirectional differentiation, including neuroendocrine, squamous, ciliated glandular, and sarcomatous components. Arch Pathol Lab Med. 2000;124:1685-7.

63. Kanno K, Hikichi T, Saito K, Watanabe K, Takagi T, Shibukawa G, et al. A case of esophageal small cell carcinoma associated with hypercalcemia causing severe acute pancreatitis. Fukushima J Med Sci. 2007;53:51-60.

64. Kitajima T, Kaida S, Lee S, Haruta S, Shinohara H, Ueno M, et al. Mixed adeno(neuro)endocrine carcinoma arising from the ectopic gastric mucosa of the upper thoracic esophagus. World J Surg Oncol. 2013;11:218.

65. Koide N, Saito H, Suzuki A, Sato T, Koiwai K, Nakamura N, Miyagawa S. Clinicopathologic features and histochemical analyses of proliferative activity and angiogenesis in small cell carcinoma of the esophagus. J Gastroenterol. 2007;42:932-8. 
66. Krishnatreya M, Kataki AC, Sharma JD, Borthakur BB, Kalita M. Epidemiology of primary small cell carcinoma of the esophagus: A retrospective study. South Asian J Cancer. 2014;3:231-2

67. Ku GY, Minsky BD, Rusch VW, Bains M, Kelsen DP, Ilson DH. Small-cell carcinoma of the esophagus and gastroesophageal junction: review of the Memorial Sloan-Kettering experience. Ann Oncol. 2008;19:533-7.

68. Kukar M, Groman A, Malhotra U, Warren GW, Bogner P, Nwogu CE, et al. Small cell carcinoma of the esophagus: a SEER database analysis. Ann Surg Oncol. 2013;20:4239-44.

69. Kuo CH, Hsieh CC, Chan ML, Li AF, Huang MH, Hsu WH, Hsu HS. Small cell carcinoma of the esophagus: a report of 16 cases from a single institution and literature review. Ann Thorac Surg. 2011;91:373-8

70. Kuriry H, Swied AM. Large-Cell Neuroendocrine Carcinoma of the Esophagus: A Case from Saudi Arabia. Case Rep Gastroenterol. 2015;9:327-34.

71. Lam KY, Law S, Tung PH, Wong J. Esophageal small cell carcinomas: clinicopathologic parameters, p53 overexpression, proliferation marker, and their impact on pathogenesis. Arch Pathol Lab Med. 2000;124:228-33

72. Law SY, Fok M, Lam KY, Loke SL, Ma LT, Wong J. Small cell carcinoma of the esophagus. Cancer. 1994:73:2894-9.

73. Lee YT, Chiu PW, Choi PC, Sung JJ. Esophageal small-cell cancer mimicking stromal tumor. Endoscopy. 2006;38(Suppl 2):E21-2.

74. Lee CG, Lim YJ, Park SJ, Jang BI, Choi SR, Kim JK, et al. Neuroendocrine tumor study group. The clinical features and treatment modality of esophageal neuroendocrine tumors: a multicenter study in Korea. BMC Cancer. 2014:14:569.

75. Li J, Chen X, Shen Y, Hou Y, Zhang S, Wang H, et al. A rare collision tumor of squamous carcinoma and small cell carcinoma in esophagus involved with separate lymph nodes: a case report. J Thorac Dis. 2013;5:E203-6.

76. Lichtenstein S, Albert NE, Muchnik A, Abraham M. Small cell carcinoma: an unusual location in a young healthy female. J Gastrointestin Liver Dis. $2011 \cdot 20: 427-30$.

77. Lim CS, Park SJ, Park MI, Moon W, Kim HH, Lee JS, et al. Successful endoscopic mucosal resection of a low esophageal carcinoid tumor. Clin Endosc. 2013;46:576-8.

78. Lü JM, Liang J, Wang JW, He J, Xiao ZF, Zhang HX, et al. [Clinical analysis of 126 patients with primary small cell carcinoma of the esophagus]. Zhonghua Zhong Liu Za Zhi. 2009;31:121-5.

79. Lu J, Xue LY, Lu N, Zou SM, Liu XY, Wen P. Superficial primary small cell carcinoma of the esophagus: clinicophatological and immunohistocemical analysis of 15 cases. Dis Esophagus. 2010;23:153-9.

80. Lu XJ, Luo JD, Ling Y, Kong YZ, Feng LL, Zhou J, Wang F. Management of Small Cell Carcinoma of Esophagus in China. J Gastrointest Surg. 2013;17:118187.

81. Macaigne G, Boivin JF, Chayette C, Chaieb S, Deplus R. [Small-cell carcinoma of the esophagus: presentation of a case and review of the literature]. Gastroenterol Clin Biol. 1999;23:988-90.

82. Madroszyk A, Egreteau J, Martin L, Queneau PE, Bosset JF, Merrouche Y Small-cell carcinoma of the esophagus: report of three cases and review of the literature with emphasis on therapy. Ann Oncol. 2001;12:1321-5.

83. Maheswari GK, Baboo HA, Patel MH, Gopal U, Wadhwa MK. Primary malignant carcinoid tumor of the esophagus. Turk J Cancer. 2000;30:40-3.

84. Makino H, Tajiri T, Onda M, Sasajima K, Miyashita M, Nomura T, et al. Effectiveness of preoperative chemotherapy using carboplatin (CBDCA) and surgery against an esophageal mall cell carcinoma. Dis Esophagus. 2002;15:237-41.

85. Martin R, Natesha RK, Hsu HK, Thompson I, Hoover EL. Synchronous small cell and squamous cell carcinoma of the esophagus: case report and review of embryogenesis. J Tenn Med Assoc. 1988;81:288-90.

86. Maru DM, Khurana H, Rashid A, Correa AM, Anandasabapathy S, Krishnan S, et al. Retrospective study of clinicopathologic features and prognosis of high-grade neuroendocrine carcinoma of the esophagus. Am J Surg Pathol. 2008:32:1404-11.

87. Fattahi Masoum SH, Sharifi N, Taraz Jamshidi S, Sharifian A, Rezaee R. Primary Small Cell Carcinoma of the Esophagus (PSCEC) Associated with Paraneoplastic Sweating Syndrome: A Case Report and Literature Review. Iran J Otorhinolaryngol. 2015;27:463-7.

88. Matsuda K, Sakurada K, Kokubo Y, Sato S, Nakazato Y, Kayama T. Esophagea neuroendocrine tumor metastatic to the pineal region. Brain Tumor Pathol. 2014;31:192-7

89. Matsunaga M, Miwa K, Noguchi T, Sasaki Y. Small cell carcinoma of gastro-oesophageal junction with remarkable response to chemo-radiotherapy. BMJ Case Rep. 2012;2012.

90. Matsuoka M, Boku N, Yoshino T, Hironaka S, Onozawa Y, Fukutomi A, et al. Small cell carcinoma of the esophagus responding to fourth-line chemotherapy with weekly paclitaxel. Int J Clin Oncol. 2005;10:429-32.

91. Matsusaka T, Watanabe H, Enjoji M. Anaplastic carcinoma of the esophagus. Report of three cases and their histogenetic consideration. Cancer. 1976;37:1352-8.
92. McCullen M, Vyas SK, Winwood PJ, Loehry CA, Parham DM, Hamblin T. Longterm survival associated with metastatic small cell carcinoma of the esophagus treated by chemotherapy, autologous bone marrow transplantation, and adjuvant radiation therapy. Cancer. 1994;73:1-4

93. Medgyesy CD, Wolff RA, Putnam JB Jr, Ajani JA. Small cell carcinoma of the esophagus: the University of Texas M. D. Anderson Cancer Center experience and literature review. Cancer. 2000;88:262-7.

94. Mimori K, Mori M, Kuwano H, Sugimachi K. Hyperthermochemoradiotherapy is effective for small cell carcinoma of the esophagus. J Surg Oncol. 1995;59:63-6.

95. Mitani M, Kuwabara Y, Shinoda N, Sato A, Fujii Y. Long-term survivors after the resection of limited esophageal small cell carcinoma. Dis Esophagus. 2000;13:259-61

96. Mori M, Matsukuma A, Adachi Y, Miyagahara T, Matsuda H, Kuwano H, et al. Small cell carcinoma of the esophagus. Cancer. 1989;63:564-73.

97. Muguruma K, Ohira M, Tanaka H, Kubo N, Yamashita Y, Sawada T, et al. Long-term survival of advanced small cell carcinoma of the esophagus after resection: a case report. Anticancer Res. 2013;33:595-600.

98. Mulder LD, Gardiner GA, Weeks DA. Primary small cell carcinoma of the esophagus: case presentation and review of the literature. Gastrointest Radiol. $1991 ; 16: 5-10$

99. Nakajima Y, Zenda S, Minashi K, Yano T, Tahara M, Doi T, et al. Non-surgical approach to small cell carcinoma of the esophagus: does this rare disease have the same tumor behavior as SCLC? Int J Clin Oncol. 2012;17:610-5.

100. Nawroz IM. Malignant carcinoid tumour of oesophagus. Histopathology. 1987;11:879-80

101. Nayal B, Vasudevan G, Rao AC, Kudva R, Valliathan M, Mathew M, Rao L. Primary Small Cell Carcinoma of The Esophagus - An Eight Year Retrospective Study. J Clin Diagn Res. 2015;9:EC04-6.

102. Nemoto K, Zhao HJ, Goto T, Ogawa Y, Takai Y, Matsushita H, et al. Radiation therapy for limited-stage small-cell esophageal cancer. Am J Clin Oncol. 2002;25:404-7.

103. Nevarez A, Saftoiu A, Bhutani MS. Primary small cell carcinoma of esophagus: clinic-pathological features and therapeutic options. Current Health Sciences Journal. 2011;37:31-4

104. Nichols GL, Kelsen DP. Small cell carcinoma of the esophagus. The Memorial Hospital experience 1970 to 1987 . Cancer. 1989;64:1531-3.

105. Tokunaga N, Itaba S, Nakamura K, Yamada M, Okamoto R, Aso A, et al. [A case of lymph node metastasis from esophageal small-cell-type endocrine cell carcinoma diagnosed by endoscopic ultrasound-guided fine-needle aspiration]. Nihon Shokakibyo Gakkai Zasshi. 2012;109:1360-6.

106. Nishimaki T, Suzuki T, Fukuda T, Aizawa K, Tanaka O, Muto T. Primary small cell carcinoma of the esophagus with ectopic gastrin production. Report of a case and review of the literature. Dig Dis Sci. 1993;38:767-71.

107. Noguchi T, Takeno S, Kato T, Wada S, Noguchi T, Uchida Y, et al. Small cell carcinoma of the esophagus; clinicopathological and immunohistochemical analysis of six cases. Dis Esophagus. 2003;16:252-8.

108. Ohmura Y, Takiyama W, Mandai K, Doi T, Nishikawa Y. Small cell carcinoma of the esophagus: a case report. Jpn J Clin Oncol. 1997;27:95-100.

109. Okuma HS, Iwasa S, Shoji H, Takashima A, Okita N, Honma Y, et al. Irinotecan plus cisplatin in patients with extensive-disease poorly differentiated neuroendocrine carcinoma of the esophagus. Anticancer Res. 2014;34:5037-41.

110. Okumura T, Shimada Y, Omura T, Hirano K, Nagata T, Tsukada K. MicroRNA profiles to predict postoperative prognosis in patients with small cell carcinoma of the esophagus. Anticancer Res. 2015;35:719-27.

111. Liñán Padilla A, Milla Sabas A, Abad Zamora JM, Vázquez Medina A, Ibáñez F, Alcántara F, Hernández de la Torre JM. [Oat-cell carcinoma of the esophagus presentation of two cases and literature review]. Rev Esp Enferm Dig. 2007;99:415-9.

112. Pantvaidya GH, Pramesh CS, Deshpande MS, Jambhekar NA, Sharma S, Deshpande RK. Small cell carcinoma of the esophagus: the Tata Memorial Hospital experience. Ann Thorac Surg. 2002;74:1924-7.

113. Partensky C, Chayvialle JA, Berger F, Souquet JC, Moulinier B. Five-year survival after transhiatal resection of esophageal carcinoid tumor with a lymph node metastasis. Cancer. 1993;72:2320-2.

114. Poynton AR, Walsh TN, Kelly A, Harney M, Stuart R, Daly PA, Hennessy TP. Small cell carcinoma of the oesophagus. Eur J Surg Oncol. 1997;23:509-12.

115. Purdy S, Gaffney EF. Ultrastructural and immunocytochemical definition of component neoplasms in an unusual gastro-oesophageal collision tumour. Histopathology. 1986;10:525-34.

116. Raja S, Rice TW, Rajeswaran J, Zhong J, Blackstone EH. Esophageal Small-Cell Cancer: Study of a Rare Disease. Dis Esophagus. 2013;26:690-5.

117. Rankin R, Nirodi NS, Browne MK. Carcinoid tumour of the oesophagus: report of a case. Scott Med J. 1980;25:245-9.

118. Ready AR, Soul JO, Newman J, Matthews HR. Malignant carcinoid tumour of the oesophagus. Thorax. 1989;44:594-6. 
119. Reid HA, Richardson WW, Corrin B. Oat cell carcinoma of the esophagus Cancer. 1980;45:2342-7.

120. Rekhtman N. Neuroendocrine Tumors of the Lung. An Update. Arch Pathol Lab Med. 2010;134:1628-38

121. Reyes CV, Chejfec G, Jao W, Gould VE. Neuroendocrine carcinomas of the esophagus. Ultrastruct Pathol. 1980;1:367-76.

122. Rice TW, Blackstone EH, Rusch VW. 7th Edition of AJCC Cancer Staging Manual: Esophagus and Esophagogastric Junction. Ann Surg Oncol. 2010;17:1721-4

123. Rosenthal SN, Lemkin JA. Multiple small cell carcinomas of the esophagus. Cancer. 1983;51:1944-6.

124. Sabanathan S, Graham GP, Salama FD. Primary oat cell carcinoma of the oesophagus. Thorax. 1986;41:318-21.

125. Sahai P, Baghmar S, Nath D, Arora S, Bhasker S, Gogia A, Sikka K, Kumar R, Chander S. Extrapulmonary Small Cell Carcinoma - a Case Series of Oropharyngea and Esophageal Primary Sites Treated with Chemo-Radiotherapy. Asian Pac J Cancer Prev. 2015;16:7025-9.

126. Sahnane N, Furlan D, Monti M, Romualdi C, Vanoli A, Vicari E, et al. Microsatellite unstable gastrointestinal neuroendocrine carcinomas: a new clinicopathologic entity. Endocr Relat Cancer. 2015;22:35-45.

127. Sato T, Mukai M, Ando N, Tashiro Y, Iri H, Abe O, Watanabe Y. Small cell carcinoma (non-oat cell type) of the esophagus concomitant with invasive squamous cell carcinoma and carcinoma in situ. A case report. Cancer. 1986;57:328-32.

128. Saw EC, Yu GS, Wagner G, Heng Y. Synchronous primary neuroendocrine carcinoma and adenocarcinoma in Barrett's esophagus. J Clin Gastroenterol. 1997;24:116-9.

129. Schuerle T, Aoun E, Farah K. Small cell carcinoma of the oesophagus: a rare cause of dysphagia. BMJ Case Rep. 2013. doi: 10.1136/bcr-2013-200468.

130. Shimoda T, Koizumi W, Tanabe S, Higuchi K, Sasaki T, Nakayama N, et al. Small-cell carcinoma of the esophagus associated with a paraneoplastic neurological syndrome: a case report documenting a complete response. Jpn J Clin Oncol. 2006;36:109-12.

131. Shinohara Y, Takeno S, Takahashi Y, Moroga T, Yamashita S, Kawahara K. Successful chemoradiotherapy for small-cell carcinoma of the esophagus in an octogenarian Japanese woman: report of the oldest case and review of long-term survival cases. Ann Thorac Cardiovasc Surg. 2014;20:237-42.

132. Shirafuji T, Kanda F, Sekiguchi K, Higuchi M, Yokozaki H, Tanaka K, Takahashi H, Toda T. Anti-Hu-associated paraneoplastic encephalomyelitis with esophageal small cell carcinoma. Intern Med. 2012;51:2423-7.

133. Siegal A, Swartz A, Aronheim M. Malignant carcinoid tumour of the oesophagus. Thorax. 1991;46:76.

134. Song Y, Wang W, Tao G, Zhu W, Zhou X, Pan P. Survival benefit of radiotherapy to patients with small cell esophagus carcinoma - An analysis of Surveillance Epidemiology and End Results (SEER) data. Oncotarget. 2015. doi:10.18632/ oncotarget.6764.

135. Sun KL, He J, Cheng GY, Chai LX. Management of primary small cell carcinoma of the esophagus. Chin Med J (Engl). 2007;120:355-8.

136. Tanabe G, Kajisa T, Shimazu H, Yoshida A. Effective chemotherapy for small cell carcinoma of the esophagus. Cancer. 1987;60:2613-6

137. Tanaka T, Matono S, Nagano T, Nishimura K, Murata K, Yamana H, et al Surgical management for small cell carcinoma of the esophagus. Dis Esophagus. 2010;23:502-5.

138. Terada T. Small cell neuroendocrine carcinoma of the esophagus: report of 6 cases with immunohistochemical and molecular genetic analysis of KIT and PDGFRA. Int J Clin Exp Pathol. 2013;6:485-91.

139. Tetreault SA, Kossman C, Mason J. Syngeneic bone marrow transplantation for small cell carcinoma of the esophagus. Bone Marrow Transplant. 1999;24:813-4

140. Travis, WD, Brambilla, E, Muller-Hermelink, HK, Harris, CC. The concept of pulmonary neuroendocrine tumours. In: Pathology \& Genetics: Tumours of the Lung, Pleura, Thymus, and Heart. IARC Press, Lyon 2004; p.19.

141. Veits L, Lang-Schwarz C, Volkholz H, Falkeis C, Vieth M, Schulz H. Mixed adenoneuroendocrine carcinoma (MANEC) of the esophagogastric junction predominantly consisting of poorly differentiated neuroendocrine carcinoma. Endoscopy. 2013;45(Suppl 2)UCTN:E16-7.
142. Vera-Mémdez FJ, Barón JM, Hallal H, García-Solano J, Martínez-Albadalejo M. [Primary undifferentiated small cell carcinoma of the esophagus: case report and literature review]. Gastroenterol Hepatol. 2001;24:410-1.

143. Vos B, Rozema T, Miller RC, Hendlisz A, Van Laethem JL, Khanfir K, Weber DC El Nakadi I, Van Houtte P. Small cell carcinoma of the esophagus: a multicenter Rare Cancer Network study. Dis Esophagus. 2011;24:258-64.

144. Wakahama O, Nishikawa S, Miyashita K, Kudou T, Nagasaka A, Higuchi A. Carcinoid tumor of the esophagus: report of a case. Gastroenterol Endosc. 2000;42:1058-62.

145. Walker SJ, Steel A, Cullen MH, Matthews HR. Treatment of oesophageal smal cell carcinoma by combined chemotherapy and surgical resection: report of two cases and review of published cases. Thorax. 1989;44:751-2.

146. Wilson CI, Summerall J, Willis I, Lubin J, Inchausti BC. Esophageal collision tumor (Large cell neuroendocrine carcinoma and papillary carcinoma) arising in a Barrett esophagus. Arch Pathol Lab Med. 2000;124:411-5.

147. Wu Z, Ma JY, Yang JJ, Zhao YF, Zhang SF. Primary small cell carcinoma of esophagus: report of 9 cases and review of literature. World J Gastroenterol 2004; $10: 3680-2$

148. Xie MR, Xu SB, Sun XH, Ke L, Mei XY, Liu CQ, Ma DC. Role of surgery in the management and prognosis of limited-stage small cell carcinoma of the esophagus. Dis Esophagus. 2015;28:476-82.

149. Yachida S, Matsushita K, Usuki H, Wanibuchi H, Maeba T, Maeta H. Long-term survival after resection for small cell carcinoma of the esophagus. Ann Thorac Surg. 2001;72:596-7.

150. Yagi M, Abe Y, Sasaki Y, Nomura E, Sato T, Iwano D, et al. Esophageal carcinoid tumor treated by endoscopic resection. Dig Endosc. 2015;27:527-30.

151. Yamamoto J, Ohshima K, Ikeda S, Iwashita A, Kikuchi M. Primary esophagea small cell carcinoma with concomitant invasive squamous cell carcinoma or carcinoma in situ. Hum Pathol. 2003:34:1108-15.

152. Yamamoto S, Tsuda H, Sakano T, Aikoh S, Tamai S, Matsubara O. Esophagea pleomorphic giant cell carcinoma combined with small cell carcinoma. Pathol Int. 2007;57:523-8

153. Yan H, Wang R, Jiang S, Zhu K, Feng R, Xu X, Meng X. NSE can predict the sensitivity to definitive chemoradiotherapy of small cell carcinoma of esophagus. Med Oncol. 2014;31:796.

154. Yang L, Sun X, Zou Y, Meng X. Small cell type neuroendocrine carcinoma colliding with squamous cell carcinoma at esophagus. Int J Clin Exp Pathol. 2014;7:1792-5.

155. Yau KK, Siu WT, Wong DC, Chau CH, Li AC, Law BK, Li MK. Non-operative management of small cell carcinoma of esophagus. Dis Esophagus. 2007;20 487-90

156. Yazıcı O, Ozdemir NY, Sendur MA, Aksoy S, Zengin N. Current approaches for prophylactic cranial irradiation in extrapulmonary small cell carcinoma. Curr Med Res Opin. 2014;30:1327-36.

157. Yekeler E, Koca T, Vural S. A rare cause of the cough: primary small cell carcinoma of esophagus-case report. Case Rep Med. 2012;2012:870783.

158. Yun JP, Zhang MF, Hou JH, Tian QH, Fu J, Liang XM, Wu QL, Rong TH. Primary small cell carcinoma of the esophagus: clinicopathological and immunohistochemical features of 21 cases. BMC Cancer. 2007;7:38.

159. Zhan XK, Sun YK, Zhang W, Wang JW. [Clinical analysis of 81 cases with primary small cell carcinoma of the esophagus]. Zhonghua Zhong Liu Za Zhi. 2008;30:926-9.

160. Zhang Z, Xiao H, Xie F, Zhang H, Chen C, Xiao H, et al. High-incidence of PTEN mutations in Chinese patients with primary small cell carcinoma of the esophagus. BMC Cancer. 2014;14:19.

161. Zhou Q, Zou BW, Xu Y, Xue JX, Meng MB, Liu FJ, et al. DNA repair gene polymorphisms and clinical outcome of patients with primary small cell carcinoma of the esophagus. Tumour Biol. 2015;36:1539-48.

162. Zhu Y, Qiu B, Liu H, Li Q, Xiao W, Hu Y, Liu M. Primary small cell carcinoma of the esophagus: review of 64 cases from a single institution. Dis Esophagus. 2014;27:152-8. 